\title{
Hepatitis A Virus PCR Analysis and $E$. coli Detection in Oysters at Oualidia Lagoon and Their Correlation
}

\author{
Naima El Moqri', Najwa Hassou1, Fatiha El Mellouli², Hasnae Zekhnini², Nabil Abouchoaib², \\ Samira Etahiri ${ }^{1}$ \\ ${ }^{1}$ Marine Biotechnology and Environment Laboratory, Faculty of Sciences El Jadida, Chouaib Doukkali University, El Jadida, \\ Morocco \\ ${ }^{2}$ Casablanca Regional Research and Analysis Laboratory, National Office of Food Safety (ONSSA), Casablanca, Morocco \\ Email: naimaelmoqri@gmail.com
}

How to cite this paper: El Moqri, N., Hassou, N., El Mellouli, F., Zekhnini, H., Abouchoaib, N. and Etahiri, S. (2020) Hepatitis A Virus PCR Analysis and E. coli Detection in Oysters at Oualidia Lagoon and Their Correlation. Food and Nutrition Sciences, 11, 684-694.

https://doi.org/10.4236/fns.2020.117049

Received: June 1, 2020

Accepted: July 11, 2020

Published: July 14, 2020

Copyright $\odot 2020$ by author(s) and Scientific Research Publishing Inc. This work is licensed under the Creative Commons Attribution International License (CC BY 4.0).

http://creativecommons.org/licenses/by/4.0/ (c) (i) Open Access

\begin{abstract}
The present study aims to evaluate hepatitis A virus (HAV) prevalence and faecal contamination indicators Escherichia coli (E. coli) in oysters from Oualidia lagoon (Moroccan Atlantic coast) and to study the correlation between the two parameters. The survey was carried out on 87 samples of oysters (Crassostrea gigas) collected monthly between November 2015 and February 2017 from three sites corresponding to different oyster farms in the lagoon. Sanitary status of bivalve molluscs was assessed by $E$. coli enumeration using ISO 16649-3. Detection of hepatitis A virus, was carried out by real-time reverse transcriptase polymerase chain reaction (rRT-PCR) according to ISO 15216-2 method. The prevalence of samples for which E. coli contamination exceeds the threshold of 230 E. coli $100 \mathrm{~g}$ of flesh and intravalvular fluid (FIF) is $43 \%$. HAV RNA was detected in $2 \%$ of the samples analyzed. This RNA was even detected in a sample meeting the bacterial criteria. Viral health surveillance of bivalve molluscs is therefore necessary before their delivery for human consumption.
\end{abstract}

\section{Keywords}

Hepatitis A Virus, E. coli, Bivalves, Shellfish, RT-PCR, Oualidia Lagoon

\section{Introduction}

Contaminated shellfishes are frequently involved in foodborne diseases and infections. Coastal marine ecosystem is threatened by a wide range of pollutants that filter-feeding molluscs can accumulate in their tissues and are therefore likely 
to cause a serious risk for consumer's health [1] [2] [3]. Viral persistense has been demonstrated in bivalve molluscs and as they are often consumed raw or slightly cooked, the microbial risk is therefore increased. [3] [4] [5] [6].

Enteric viruses of human origin are very common in seawater where they are rejected in large amount, shed by infected people [7].

They belong to a large panel of family and genus and among this diversity, $\mathrm{HAV}$, ranked as priority hazards by $\mathrm{WHO} / \mathrm{FAO}$, is known since antiquity to be responsible for many epidemics, causing acute inflammation of the liver [8]. Nowadays it is still implicated in several outbreaks around world as 1.4 millions clinical cases occur annually [9].

This illness is strongly related to age: if it is a mild disease in children under five, protective antibodies bestow lifelong immunity, in older children and adults may have acute inflammation of the liver with icteric symptomatology, though without involving chronic liver disease [10]. Healing is current; however, in rare cases, it can lead to fulminant hepatitis that progresses to a fatal outcome. The economic burden is significant as recovery can be long and disabling [11].

$\mathrm{HAV}$ is a member of the Picornaviridae family, genus Hepatovirus [12]. Although known as limited to man and some species of non-human primates [13], presence of HAV has been recently detected in animals other than primates as seals [14], woodchuck [15] and marsupials [16]. A single serotype is present in human and strains are classified into six genotypes [17]. Very resistant under various conditions of environment, it can survive, and remain infectious, for a long period outside a host [18]. Epidemics occur in a cyclical manner by fecal-oral transmission and close contact with infected persons and contaminated food and water [19].

HAV outbreaks linked to consumption of bivalve molluscs represent $17 \%$ of total foodborne outbreaks [5]. These outbreaks occur as a consequence of the contamination of surrounding water by pathogens.

Currently, microbiological surveillance of bivalve molluscs is based solely on bacteriological parameters. Moroccan regulation (decision $n^{\circ}$ 1950-17 of 07/08/2017 of Moroccan Ministry of Agriculture, Rural Development and Maritime Fisheries) requires a sanitary control of harvesting shellfish areas by enumeration of $E$. coli as faecal indicator bacteria. Four classes are identified according to their microbiological quality: A ( $80 \%$ of samples < 230 E. coli per $100 \mathrm{~g}$ of shellfish flesh and intravalvular fluid (FIF) and the remaining $20 \%$ of samples $<700 E$. coli per $100 \mathrm{~g}$ of FIF), B (90\% of samples $<4600 \mathrm{E}$. coli per $100 \mathrm{~g}$ of FIF and the remaining $10 \%$ of samples $4600 \leq E$. coli $\leq 46,000$ per $100 \mathrm{~g}$ of FIF), and C ( $100 \%$ of samples $E$. coli $\leq 46,000$ per $100 \mathrm{~g}$ of shellfish FIF). However, several studies have shown that bacteria are not reliable indicators of viral contamination in shellfish [20] [21].

The aim of our study was to evaluate hepatitis A virus prevalance in oysters harvested at Oualidia lagoon, using real-time RT-PCR analysis according to the ISO 15216-2 method as well as the enumeration of $E$. coli performed in accordance with ISO/TC 16649-3. 


\section{Materials and Methods}

\subsection{Description of Study Area}

Oualidia is a lagoon without outlet, located on the Atlantic coast, $168 \mathrm{~km}$ south of Casablanca, at $\left(32^{\circ} 46^{\prime} \mathrm{N}, 09^{\circ} 01^{\prime} \mathrm{W}\right)$. It is listed as RAMSAR site (wetlands of international importance).

It communicates with the ocean through a major inlet of $150 \mathrm{~m}$ wide and a secondary one of $50 \mathrm{~m}$. The sedimentation is sandy near the passes and silty upstream where turbidity is higher in the rainy season, between October and April [22]. An artificial dam contributes to trap sedimentary organic matters and protects this ecosystem from confinement. Anthropic pressure on this ecosystem is linked to agriculture, tourism, oyster farming and urbanization. Even if some residential on the shoreline only have septic tanks, the commissioning of the treatment plant in 2012 helped reduce this pressure.

Renowned for its oysters with a production close to 36 tons annualy, Oualidia lagoon is classified as a " $\mathrm{B}$ " harvesting area. Therefore, depuration processing is a statutory requirement before marketing for human consumption.

\subsection{Shellfish Sampling}

Oyster samples ( $\mathrm{n}=12$ individuals/sample) were collected, over 16 months between November 2015 and February 2017, twice per month except for May and June where the sample has been taken only once, giving a total of 87 samples. Sampling sites (S1, S2 and S3) correspond to three oyster farms located in Oualidia Lagoon. S1 is located downstream of the lagoon near the principal pass with a sandy sedimentary facies. S2 and S3 are further upstream, before inner dam location, and are characterized by muddy sediment (Figure 1).

Bivalve molluscs were transported to the laboratory under controlled temperature $\left(+4^{\circ} \mathrm{C}\right)$ within 24 hours. The samples were processed rapidly for Escherichia coli and for HAV or stored at $-80^{\circ} \mathrm{C}$.

\subsection{Viral RNA Extraction}

To evaluate the presence of HAV, RNA extraction method included the use of guanidine isothiocyanate as chaotropic agent. Shellfish were thawed, cleaned and shukked in sterile conditions, the hepatopancreas was removed and chopped using a razor blade. $2.0 \pm 0.2 \mathrm{~g}$ subsample of digestive tissues was transferred to clean tube and mixed with $10 \mu \mathrm{l}$ of mengovirus as a process control of nucleic acid extraction (Ceeramtools $\left.{ }^{\circledR}\right) .2 \mathrm{ml}$ of Protéinase $\mathrm{K}$ solution $(100 \mu \mathrm{l} / \mathrm{ml}$ ) was added to digest the tissues that were incubated with shaking $\left(37^{\circ} \mathrm{C} \pm 1.0^{\circ} \mathrm{C} / 320 \pm\right.$ $20 \mathrm{rpm})$ for $60 \mathrm{~min}$ followed by a second incubation $\left(60^{\circ} \mathrm{C} \pm 2.0^{\circ} \mathrm{C} / 15 \mathrm{~min}\right)$. Then samples were centrifuged at $3000 \mathrm{~g}$ for $5 \mathrm{~min}$ and the supernatant collected in a clean tube. RNA was extracted from $500 \mu \mathrm{l}$ and eluted in $100 \mu \mathrm{l}$ of elution buffer using commercial Nucleospin RNA virus kit (Macherey Nagel, Germany) following the manufacturer's instruction. RNA was tested for HAV immediately or stored at $-20^{\circ} \mathrm{C}$ until use. 


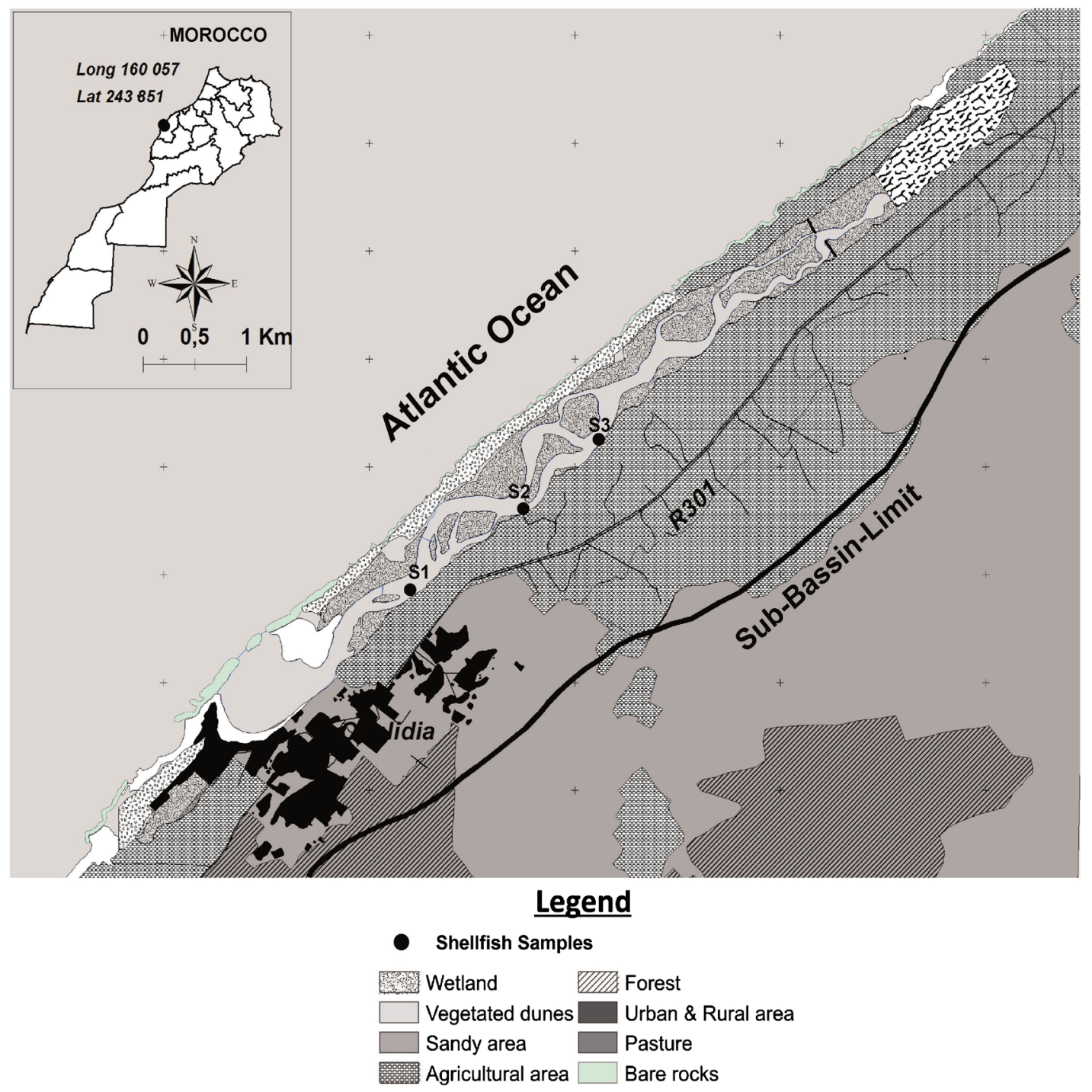

Figure 1. Shellfish collection sites.

\subsection{One-Step qRT-PCR}

HAV, HAV68 and HAV240 primers and HAV150 probe [23], and Mengovirus vMCO strain (Ceeramtools ${ }^{\circledR}$ ) were used. $5 \mu$ of each RNA sample was amplified in $25 \mu \mathrm{l}$ total volume with one-step reaction mix prepared using the SuperScript ${ }^{\circledR}$ III Platinum ${ }^{\circledR}$ One-Step Quantitative RT-PCR Kit (Invitrogen) that contained $1 \times$ reaction mix, $0.5 \mathrm{pmol} / \mu \mathrm{l}$ of forward primer, $0.9 \mathrm{pmol} / \mu \mathrm{l}$ of reverse primer and $0.25 \mathrm{pmol} / \mu \mathrm{l}$ of probe, $1 \times$ ROX Reference Dye and $1.25 \mu \mathrm{l}$ of SuperScript ${ }^{\circledR}$ III RT/Platinum ${ }^{\circledR}$ Taq mix. The set of primers and probes and their reference are listed in Table 1. Amplification was performed in a 7500 Fast Real-time PCR System (Applied Biosystems) using the following cycling parameters: reverse transcription at $50^{\circ} \mathrm{C}$ for $60 \mathrm{~min}$, denaturation at $95^{\circ} \mathrm{C}$ for $5 \mathrm{~min}$, followed by 40 cycles of amplification with a denaturation at $95^{\circ} \mathrm{C}$ for $15 \mathrm{~s}$ and annealing and extension at $60^{\circ} \mathrm{C}$ for $1 \mathrm{~min}$.

Viral RNA extracted from each sample was tested undiluted and at a tenfold 
dilution to evaluate the presence of inhibitors. A Ct value difference $<3.3$ indicated the presence of inhibitors. In each operation, a Mengovirus standard curve was generated by a 10 -fold serial dilution. Extraction efficiency was evaluated by comparing the $\mathrm{Ct}$ value of RNA of Mengovirus extracted from the samples to those obtained for the standard curve. Results $\geq 1 \%$ were considered valid. Wells containing nuclease free water as negative control and HM 175 strain of HAV as positive control were tested in parralel with each batch of samples.

\subsection{E. coli Enumeration}

Samples were analyzed for $E$. coli enumeration using most probable number (MPN) method in accordance with ISO/TS 16649-3: horizontal method for enumeration of beta-glucuronidase-positive Escherichia coli. The most probable number (MPN) of E. coli is calculated using the tables of ISO 7218: 2007). Whole oysters (flesh and intravalvular fluid) were homogenized by stomacher in peptone saline diluent followed by decimal dilution. A series of five tubes were inoculated, containing double strength minerals modified glutamate medium (MMGM), single strength MMGM, and 10-1, 10-2 and 10-3 dilutions of single strength MMGM. They were incubated at $37^{\circ} \mathrm{C} \pm 1^{\circ} \mathrm{C}$ for $24 \pm 2 \mathrm{H}$. Thereafter, tubes showing trace of acid production are subcultured in tryptone bile glucuronide agar (TBX) and incubated at $44^{\circ} \mathrm{C} \pm 1^{\circ} \mathrm{C}$ for $22 \mathrm{H} \pm 2$ $\mathrm{H}$. The plates yielding growth of blue-green colony indicate Escherichia coli $\beta$-glucuronidase-positive.

\section{Results}

\subsection{Evaluation of Viral Contamination in Shellfish Samples}

Among the 87 samples analysed, 2\% were HAV positive. The HAV-positive samples were collected during the winter after a rainy-period, in November 2015 and January 2016 (Table 2). Regarding the sampling sites, the two HAV-positive samples were from S3 located the most upstream.

Table 1. Sequences of the primers used for HAV detection.

\begin{tabular}{llc}
\hline Virus & \multicolumn{1}{c}{ Primer sequence } & Reference \\
\hline & Forward primer VHA68 & {$[23]$} \\
& 5'-TCA CCG CCG TTT GCC TAG-3' & \\
HAV & Reverse primer VHA240 & {$[23]$} \\
& 5'-GGA GAG CCC TGG AAG AAA G-3' & \\
& Probe VHA150 & {$[23]$} \\
& FAM 5'-CCT GAA CCT GCA GGA ATT AA-3'MGBNFQ & \\
\hline
\end{tabular}

Table 2. Seasonal distribution of VHA-positive samples.

\begin{tabular}{cc}
\hline Date & HAV Positive Oysters \\
\hline November 2015 & 1 \\
January 2016 & 1 \\
\hline
\end{tabular}




\subsection{E. coli Bacterial Contamination and Correlation with Viral Contamination}

Analysis of oyster samples showed $43 \%$ are contaminated by $E$. coli and the legislation in force defines Oualidia lagoon as a "B" harvesting area ( $90 \%$ of results $\leq 4600$ E. coli FIF and $100 \% \leq 46,000$ E. coli $100 \mathrm{~g}$ of (FIF)) (Figure 2). However, contamination with hepatitis A virus is variable as a sample HAV positive showed a low contamination with $E$. coli (not exceeding 230 E. coli/100g FIF) while the other HAV positive sample showed a high rate of contamination by $E$. coli. Samples contaminated by HAV come from (S3) while RNA-HAV was not detected in samples from (S1) and (S2). Thus, our results showed no correlation between HAV and E. coli contamination p $>0.05$.

\section{Discussion}

Shellfish viral contamination data are scarce in Morocco. This study was conducted to evaluate the presence of HAV in oysters collected from different sites of the Oualidia lagoon, classified as " $\mathrm{B}$ " harvesting area. We found that $2 \%$ of the samples are contaminated with this virus.

The prevalence of contaminated oysters found in our study is low given Moroccan epidemiological context. Thus the year 2016 when most of the samples were taken, was a year od drought which reduced the incidence of soil leaching, but similar finding was reported previously [24]. Yet in the mediterranean rim countries, incidence rates of HAV are quite different between regions. It was detected in $26 \%$ of shelfish samples in Tunisia [25], 10.1\% in Spain [26] whereas all samples were HAV negative in south Italy [27]. The results obtained can be the consequence of the water renewal influenced by currents and other hydrographic variables [28] [29].

Cases of hepatitis A are reported throughout the year and seasonal pattern of HAV have not been clearly observed [30]. Although, positive samples in our study were taken during the winter period. Similar data were reported in Tunisia, Hong Kong and USA [31] [32] [33]. This result can be linked to rainfalls,

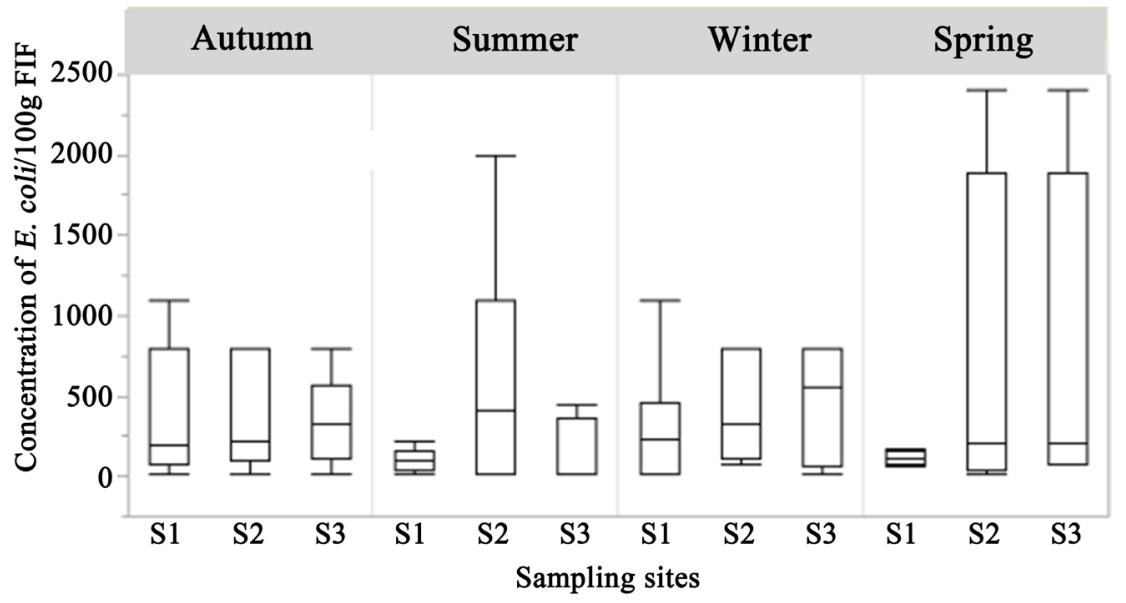

Figure 2. E. coli counts. 
which would have caused the overflow of the septic tanks. However, as the two HAV positive samples having been obtained from the same site at quite close intervals of time (november 2015 and january 2016), this would be more in favor of spot contamination linked to feces discharge of infected persons.

Hepatitis A infection is reported to have intermediate endemicity in Morroco and episodes of epidemics are scarce as most people acquire long lasting immunity at a young age when the illness is benign or asymptomatic most of the time. Improving sanitary measures leads to shifting primary infection progressively to older ages but with more severe symptoms. Thereby decreased immunity will lead to more frequent outbreaks [34]. However, the long incubation period that separates the contamination and the onset of symptoms makes it difficult to identify the source of the infectious agent. Thus, as prospective virological analyzes of shellfish are not routinely conducted, the involvement of oysters as a vector of HAV is not known.

Physical, chemical and biological factors play a role in most microorganisms stability. However HAV is outstandingly resistant to environmental conditions and may persist for a long time in food, on fomites and in water. Adsorption to solid particles is one of most relevant factor involved in its survival and retention by shellfishs [35] [36] [37] [38]. Depuration is intended to eliminate shelfish pathogens, however effectiveness of this process has not been demonstrated in HAV [39].

Indeed, the monitoring of shellfish and shellfish waters is based solely on the enumeration of Escherichia coli as an indicator of faecal contamination; the viral hazard is not taken into account. According to several studies the analyzes of fecal coliforms and E. coli. give limited predictive value for pathogenic viruses such as enteroviruses [40], noroviruses and infectious hepatitis caused by hepatitis A virus [41]. Thus, average E. coli levels in HAV positive samples correspond to a class A (220 E. coli/100g FIF for the sample taken in november 2015) as well as a class B (780 E. coli/100g FIF for the sample analyzed in January 2016). Our findings are consistent with those obtained in various studies [20] [32] [40] [42]-[49].

For a while, the search for viruses stumbled on the lack of an appropriate method. HAV barely grows in cell cultures and often fails to produce cytopathic effect [50] [51]. Appropriate method for identifying HAV in oysters, available recently, overcame this difficulty. Fast and sensitive, RT-qPCR remains the most appropriate method for detecting a low concentration of viral particles. However, this analytical technique does not differentiate between infectious and non-infectious virus particles. Thereby, presence of HAV genome might balanced by a linked-risk analysis.

\section{Conclusion}

The absence of correlation between faecal bacteria as indicators of microbiological contamination and food-borne viruses highlights the need of additional con- 
trol measures implementation. Updating existing legislation in force to include viral hazards in the monitoring of bivalve shellfish harvesting areas is an urgent matter to which the competent authorities should respond. Indeed, monitoring of foodborne viruses in bivalve molluscs may contribute to the prevention of viral food poisoning and the promotion of public health.

\section{Conflicts of Interest}

The authors declare no conflicts of interest regarding the publication of this paper.

\section{References}

[1] Desenclos, J.C. (1996) Epidemiology of Toxic and Infectious Risks Linked to the Consumption of Bivalve Molluscs. Revue d Epidémiologie et de Santé Publique, 44, 437-454. (In French)

[2] Loisy, F., Atmar, R.L., Le Saux, J.-C., Cohen, J., Caprais, M.-P., Pommepuy, M. and Le Guyader, F.S. (2005) Use of Rotavirus Virus-Like Particles as Surrogates to Evaluate Virus Persistence in Shellfish. Appied and Environmental. Microbiology, 71, 6049-6053. https://doi.org/10.1128/AEM.71.10.6049-6053.2005

[3] Schwab, K.J., Neill, F.H., Estes, M.K., Metcalf, T.G. and Atmar, R.L. (1998) Distribution of Norwalk Virus within Shellfish Following Bioaccumulation and Subsequent Depuration by Detection Using RT-PCR. Journal of Food Protection, 61, 1674-1680. https://doi.org/10.4315/0362-028X-61.12.1674

[4] Metcalf, T.G., Melnick, J.L. and Estes, M.K. (1995) Environmental Virology: From Detection of Virus in Sewage and Water by Isolation to Identification by Molecular Biology-A Trip of Over 50 Years. Annual Review of Microbiology, 49, 461-487. https://doi.org/10.1146/annurev.mi.49.100195.002333

[5] Bellou, M., Kokkinos, P. and Vantarakis, A. (2013) Shellfish-Borne Viral Outbreaks: A Systematic Review. Food and Environmental Virology, 5, 13-23.

https://doi.org/10.1007/s12560-012-9097-6

[6] Cheng, P.K., Wong, D.K., Chung, T.W. and Lim, W.W. (2005) Norovirus Contamination Found in Oysters Worldwide. Journal of Medical Virology, 76, 593-597. https://doi.org/10.1002/jmv.20402

[7] Bosh, A., Gkogka, E., Le Guyader, F.S., Loisy-Hamon, F., Lee, A., Van Lieshout, L., Marthi, B., Myrmel, M., Sansom, A., Schultz, A.C., Winkler, A., Zuber, S. and Phister, T. (2018) Foodborne Viruses: Detection, Risk, Assessment, and Control Options in Food Processing. International Journal of Food Microbiology, 285, 110-128. https://doi.org/10.1016/j.ijfoodmicro.2018.06.001

[8] Previsani, N., Lavanchy, D. and Siegl, G. (2003) Hepatitis A. Perspectives in Medical Virology, 10, 1-30. https://doi.org/10.1016/j.ijfoodmicro.2018.06.001

[9] World Health Organization (2017) Global Hepatitis Report. https://www.who.int/

[10] Cuthbert, J.A. (2001) Hepatitis A: Old and New. Clinical Microbiology Reviews, 14, 38-58. https://doi.org/10.1128/CMR.14.1.38-58.2001

[11] Dhankhar, P., Nwankwo, C., Pillsbury, M., Lauschke, A., Goveia, M.G., Acosta, C.J. and Elbasha, E.H. (2015) Public Health Impact and Cost-Effectiveness of Hepatitis A Vaccination in the United States: A Disease Transmission Dynamic Modeling Approach. Value in Health, 18, 358-367. https://doi.org/10.1016/j.jval.2015.02.004

[12] Lemon, S.M., Jansen, R.W. and Brown, E.A. (1992) Genetic, Antigenic and Biologi- 
cal Differences between Strains of Hepatitis A Virus. Vaccine, 10, 540-544. https://doi.org/10.1016/0264-410X(92)90540-Z

[13] Balayan, M.S. (1992) Natural Hosts of Hepatitis A Virus. Vaccine, 10, 27-31. https://doi.org/10.1016/0264-410X(92)90537-T

[14] Anthony, S.J., Leger, J.A.S., Liang, E., Hicks, A.L., Sanchez-Leon, M.D., Jain, K., Lefkowitch, J.H., Navaretrete-Macias, L., Knowles, N., Goldstein, T., Pugliares, K., Ip, H.S., Rowles, T. and Lipkin, W.I. (2015) Discovery of a Novel Hepatovirus (Phospivirus of Seals) Related to Human Hepatitis A Virus. American Society for Microbiology, 6, e1180-85. https://doi.org/10.1128/mBio.01180-15

[15] Yu, J.-M., Li, L.-L., Zhang, C.-Y., Lu, S., Ao, Y.-Y., Gao, H.-C., Xie, Z.-P., Xie, G.-C., Sun, X.-M., Pang, L.-L., Xu, J.-G., Lipkin, W.-I. and Duan, Z.-J. (2016) A Novel Hepatovirus Identified in Wild Woodchuck Marmota himalayana. Scientific Reports, 6, Article No. 22361. https://doi.org/10.1038/srep22361

[16] De Oliveira Carneiro, I., Sander, A.-L., Silva, N., Moreira-Soto, A., Normann,A., Flehming, B., Lukashev, A.N., Dotzauer, A., Wieseke, N., Franke, C.R. and Drexler, J.F. (2018) A Novel Marsupial Hepatitis A Virus Corroborates Complex Evolutionary Patterns Shaping the Genus Hepatovirus. Journal of Virology, 92, E00082-18. https://doi.org/10.1128/JVI.00082-18

[17] International Committee on Taxonomy of Viruses (2018) The Online (10th) Report. https://talk.ictvonline.org/

[18] Sattar, S.A., Tetro, J., Bidawid, S. and Jeff, F. (2000) Foodborne Spread of Hepatitis A: Recent Studies on Virus Survival, Transfer and Inactivation. Canadian Journal of Infectious Diseases and Medical Microbiology, 11, Article ID: 805156. https://doi.org/10.1155/2000/805156

[19] Fiore, A.E. (2004) Hepatitis A Transmitted by Food. Clinical Infectious Diseases, 38, 705-715. https://doi.org/10.1086/381671

[20] Croci, L., De Medici, D., Scalfaro, C., Fiore, A., Divizia, M., Donia, D., et al. (2000) Determination of Enteroviruses, Hepatitis A Virus, Bacteriophages and Escherichia coli in Adriatic Sea Mussels. Journal of Applied Microbiology, 88, 293-298. https://doi.org/10.1046/j.1365-2672.2000.00966.x

[21] Lees, D. (2000) Viruses and Bivalve Shellfish. International Journal of Food Microbiology, 59, 81-116. https://doi.org/10.1016/S0168-1605(00)00248-8

[22] Hassou, N., Boujaber, N., Oumaskour, K., Lakhdar, F., Benba, J., Benhaddou, Z., Assoobhei, O. and Etahiri, S. (2016) Nutrients Variation in the Coastal Waters of Oualidia Lagoon, Morocco, in Relation to the Contribution of Watershed and Hydro-Chemical Characteristics. International Journal of Advanced Research, 4, 1697-1706. https://doi.org/10.21474/IJAR01/2572

[23] Costafreda, M.I., Bosch, A. and Pintó, R.M. (2006) Development, Evaluation and Standardization of a Real-Time Taqman Reverse Transcription-PCR Assay for Quantification of Hepatitis A Virus in Clinical and Shellfish Samples. Applied and Environmental Microbiology, 72, 3846-3855. https://doi.org/10.1128/AEM.02660-05

[24] Benabbes, L., Olivier, J., Schaeffer, J., Parnaudeau, S., Rhaissi, H., Nourlil, J., et al. (2013) Norovirus and Other Human Enteric Virusesin Moroccan Shellfish. Food and Environmental Virology, 5, 35-40. https://doi.org/10.1007/s12560-012-9095-8

[25] Elamri, D. E., Aouni, M., Parnaudeau, S. and Le Guyader, F.S. (2006) Detection of Human Enteric Viruses in Shellfish Collected in Tunisia. Letters in Applied Microbiology, 43, 399-404. https://doi.org/10.1111/j.1472-765X.2006.01978.x

[26] Polo, D., Alvarez, C., Vilariño, M.L., Longa, A. and Romalde, J.L. (2014) Depuration 
Kinetics of Hepatitis A Virus in Clams. Food Microbiology, 39, 103-107. https://doi.org/10.1016/j.fm.2013.11.011

[27] La Bella, G., Martella, V., Basanisi, M.G., Nobili, G., Terio, V. and La Salandra, G. (2017) Food-Borne Viruses in Shellfish: Investigation on Norovirus and HAV Presence in Apulia (SE Italy). Food and Environmental Virology, 9, 179-186. https://doi.org/10.1007/s12560-016-9273-1

[28] Brehmer, P., Chi, T.D., Laugier, T., Galgani, F., Laloë, F., Darnaude, A.M., Fiandrino, A. and Mouillot, D. (2011) Field Investigations and Multi-Indicators for Shallow Water Lagoon Management: Perspective for Societal Benefit. Aquatic Conservation: Marine and Freshwater Ecosystems, 21, 728-742. https://doi.org/10.1002/aqc.1231

[29] Hassou, N., Maanan, M., Hennani, M., Zourarah, B. and Assobhei, O. (2014) Spatial and Temporal Variation of Faecal Pollution Indicators (Escherichia coli and Faecal streptococci) and Physico-Chemical Parameters at the Oualidia Lagoon and Its Watershed (Morocco). International Journal of Current Microbiology and Applied Sciences, 3, 675-694.

[30] Stanley, M. and Lemon, M.D. (1985) Type A Viral Hepatitis-New Developments in an Old Disease. The New England Journal of Medicine, 313, 1059-1067. https://doi.org/10.1056/NEJM198510243131706

[31] Gharbi-Khelifi, H., Sdiri, K., Ferre, V., Harrath, R., Berthome, M., Billaudel, S. and Aouni, M. (2007) A 1-Year Study of the Epidemiology of Hepatitis A Virus in Tunisia. Clinical Microbiology and Infection, 13, 25-32. https://doi.org/10.1056/NEJM198510243131706

[32] Lee, T., Yam, W.C., Ho, B.S.W., Ng, M.H. and Broom, M.J. (1999) Occurrence of Hepatitis A Virus in Green Lipped Mussels (Perna viridis). Water Research, 33, 885-889. https://doi.org/10.1016/S0043-1354(98)00269-3

[33] Woods, J.W. and Burkhardt III, W. (2010) Occurrence of Norovirus and Hepatitis A Virus in U.S. Oysters. Food and Environmental Virology, 2, 176-182. https://doi.org/10.1007/s12560-010-9040-7

[34] Jacobsen, K.H. and Wiersma, S.T. (2010) Hepatitis A Virus Seroprevalence by Age and World Region, 1990 and 2005. Vaccine, 28, 6653-6657. https://doi.org/10.1016/j.vaccine.2010.08.037

[35] Boher, S., Albert, M. and Schwartzbrod, L. (1993) Etude de la Contamination Virale des Huîtres et de leur Epuration Virale-Etude de la Contamination Virale des sédiments Marins en zone de Mytiliculture. (In French) https://archimer.ifremer.fr/doc/00131/24275/

[36] Da Silva, A.K., Le Saux, J.-C., Parnaudeau, S., Pommepuy, M., Eimelech, M. and Le Guyader, F.S. (2007) Evaluation of Removal of Noroviruses During Wastewater Treatment, Using Real Time Reverse Transcription-PCR: Different Behaviors of Genogroups I and II. Applied and Environmental. Microbiology, 24, 7891-7897. https://doi.org/10.1128/AEM.01428-07

[37] Deloince, R., Leveque, F., Crance, J.M. and Trepo, C. (1994) Epidemiology of Viral Hepatitis A. Gastroenterologie Clinique et Biologique, 18, 354-361. (In French)

[38] Sobsey, M.D., Shields, P.A., Hauchman, F.S., Davis, A.L., Rullman, V.A. and Bosch, A. (1988) Survival and Persistence of Hepatitis A Virus in Environmental Samples. Viral Hepatitis and Liver Disease. In: Zuckerman, A.J., Ed., Viral Hepatits and Liver Disease, Alan R. Liss, New York, 121-124.

[39] Polo, D., Varela, M.F. and Romalde, J.L. (2015) Detection and Quantification of Hepatitis A Virus and Norovirus in Spanish Authorized Shellfish Harvesting Areas. 
International Journal of Food Microbiology, 193, 43-50.

https://doi.org/10.1016/j.ijfoodmicro.2014.10.007

[40] Gerba, C.P., Goyal, S.M., La Belle, R.L., Cech, I. and Bodgan G.F. (1979) Failure of Indicator Bacteria to Reflect the Occurrence of Enteroviruses in Marine Waters. American Journal of Public Health, 69, 1116-1119. https://doi.org/10.2105/AJPH.69.11.1116

[41] Desenclos, J.C., Klontz, K.C., Wilder, M.H., Naiman, O.V., Margolis, H.S. and Gunn R.A. (1991) A Multistate Outbreak of Hepatitis A Caused by the Consumption of Raw Oysters. American Journal of Public Health, 81, 1268-1272. https://doi.org/10.2105/AJPH.81.10.1268

[42] Amri, I., Hmaïed, F., Loisy, F., Lebeau, B., Barkallah, I., Saidi, M. and Slim, A. (2011) Hepatitis A Virus Detection in Shellfish from Tunisia by Reverse Transcription-Nested PCR-Investigation of a Correlation between Viral and Bacterial Contamination. Pathologie Biologie, 59, 217-22. (In French)

https://doi.org/10.1016/j.patbio.2009.10.009

[43] Bazzardi, R., Fattaccio Caterina, M., Salza, S., Canu, A., Marongiu, E. and Pisanu, M. (2014) Preliminary Study on Norovirus, Hepatitis A Virus, Escherichia coli and Their Potential Seasonality in Shellfishfrom Different Growing and Harvesting Areas in Sardinia Region. Italian Journal of Food Safety, 3, 1601.

https://doi.org/10.4081/ijfs.2014.1601

[44] Chalmers, J.W.T. and Mcmillan, J.H. (1995) An Outbreak of Viral Gastroenteritis Associated with Adequately Prepared Oysters. Epidemiology \& Infection, 115, 163-167. https://doi.org/10.4081/ijfs.2014.1601

[45] Fusco, G., Aprea, G., Galiero, G., Guarino, A. and Viscardi, M. (2013) Escherichia coli, Salmonella spp., Hepatitis A Virus and Norovirus in Bivalve Molluscs in Southern Italy. Veterinaria Italiana, 49, 55-58.

[46] Jofre, J. (1992) Bivalve Molluscs as Vectors of Human Enteric Viruses. Microbiologie Aliments Nutrition, 10, 223-228.

[47] Richards, G.P. (1985) Outbreaks of Shellfish-Associated Enteric Virus Illness in the United States: Requisite for Development of Viral Guidelines. Journal of Food Protection, 48, 815-823. https://doi.org/10.4315/0362-028X-48.9.815

[48] Richards, G.P., Mcleod, C. and Le Guyader, F.S. (2010) Processing Strategies to Inactivate Viruses in Shellfish. Food and Environmental Virology, 2, 183-193. https://doi.org/10.1007/s12560-010-9045-2

[49] Romalde, J.L., Area, E., Sánchez, G., Ribao, C., Torrado, I., Abad, X., Pintó, R.M., Barja, J.L. and Bosch, A. (2002) Prevalence of Enterovirus and Hepatitis A Virus in Molluscs from Galicia (NW Spain): Inadequacy of the EU Standards of Microbiological Quality. International Journal of Food Microbiology, 74, 119-130. https://doi.org/10.1016/S0168-1605(01)00744-9

[50] Emerson, S.U., Mcrill, C., Rosenblum, B., Feinstone, S. and Purcell, R.H. (1991) Mutations Responsible for Adaptation of Hepatitis A Virus to Efficient Growth in Cell Culture. Journal of Virology, 65, 4882-4886. https://doi.org/10.1128/JVI.65.9.4882-4886.1991

[51] Konduru, K. and Kaplan, G.G. (2006) Stable Growth of Wild-Type Hepatitis A Virus in Cell Culture. Journal of Virology, 80, 1352-1360. https://doi.org/10.1128/JVI.80.3.1352-1360.2006 